\title{
Change agency and higher education in South Africa
}

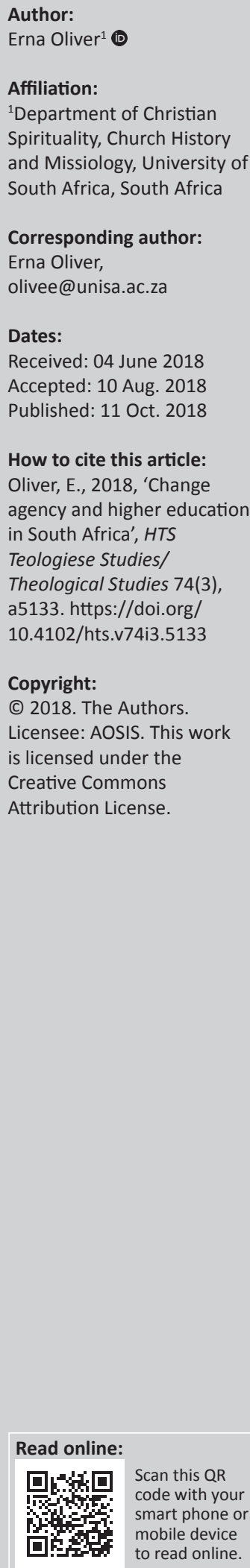

This article applies change agency to the institutions of higher education in South Africa - referring here to all the post-school institutions and educators in general and more specifically focused on the unique opportunities and responsibilities towards change agency in theological training. The focus is on the characteristics of a change agent, which could be an individual or a group. Seemingly, change is not going to be initiated in a 'top-down' approach; therefore, this article suggests a 'bottom-up' approach, starting with a change agent (an individual or a group) to become enthusiastic and active to bring about change. The method of constructivism is used, complemented by a general literature review of the past 70 years, filled with definitions of change agents and change agency. After the discussion of a few models, the researcher ventures to propose a way in which change agency can find a foothold among theological educators in higher education institutions in South Africa.

\section{Introduction}

In 1947, the National Training Laboratories Institute was founded by Kurt Lewin, Ron Lippitt and others at Bethel (Maine, United States [US]), and in that same year Lewin's staff used the term 'change agency' to facilitate discussions that took place among 'heterogenous [sic] groups of professional helpers' (Lippitt, Watson \& Westley 1958:10). This is the reason why many scholars regard Lewin as the father of concepts like change agent, action research and group dynamics (cf. Benne 1976; De Board 1978; Foster 1972; Hall \& Lindsey 1978).

\section{Currently, higher education is experiencing significant challenges, which are (Swail 2002):}

stimulated by the rapid growth of the internet, the increasing globalization of higher education, and the ever-pressing question of institutional quality. New modes of educational delivery through virtual networks are breaking the traditional mold of instructional provision. New players, new pedagogies, and new paradigms are redefining higher education. The rules are changing, and there is increased pressure on institutions of higher education to evolve, adapt, or desist. (p. 16)

In addition to these educational challenges, South Africa is, for the past 25 years, in a state of transformation which provides its own problems, one of which is that the changes made to education are not delivering the required results. This problem is, however, not unique to South Africa, as Diamond (2005) states with reference to the US:

In considering recent calls for change and the actions colleges and universities must take to respond to them, it is clear that not only are fairly fundamental changes needed in the areas of course and curricular design and pedagogy, but that these changes must be accomplished with few resources and with many factors complicating the change process. (p. 24)

This article focuses on the educator as a change agent in the learning environment and highlights the fact that institutions of higher education need significant change, which implies a paradigm shift in their educational process. As most of the educators in South Africa are not adequately equipped for this task, or sharing the passion of being a change agent, the institutions of higher education should motivate and train the educators to become part of the process of change agency. Diamond (2005:25; cf. Tagg 2003) puts it euphemistically that 'faculty and staff may not be adequately prepared for these roles in the new learning paradigm'. Some general characteristics of change agents as well as a short list of characteristics that theological educators should embrace are included as pointers towards stimulating educators to become positive agents of change.

\section{Methodology}

In this article, change agency is implemented against the backdrop of constructivism. Constructivism became popular during the second half of the 20th century (cf. Attard 2010:8). 
Other theories like behaviourism and cognitivism were also introduced but did not gain the popularity of constructivism (Ally 2004:7; cf. Alzahrani \& Woollard 2013:1-9; Bada 2015:66-70). Ally (2004:7) suggests an interaction between the three theories, combining the strong points of each strategy: behaviourist strategies are more focused on the teaching of facts (the 'what'), while cognitivist strategies lay more emphasis on the principles and processes (the 'how'). This will then link to the constructivist strategies where real-life and personal applications together with contextual learning are on the foreground. However, a mixture of these theories or strategies is not recommended, as constructivism also links with the 'what' and the 'how' as part of a complete strategy.

According to the theory of constructivism, the learning process only takes place when a person experiences something that does not fit within his or her cognitive schemes - this creates a cognitive disequilibrium, resulting in adaptation, implying that a re-equilibrium is taking place where the person then adopts the new experience. The implication is that knowledge is only successfully created when someone actively makes sense of his or her personal experiential worlds (MacLellan \& Soden 2004:254).

It has been stated above that constructivism opposes the traditional learning methods, as the bulk of them are not yet, or not completely, student-centred (cf. Bada 2015:66). This means that educators should continuously undergo professional development to deliver innovative teaching (cf. Attard 2010:11) and learn how to enhance students' critical thinking. The educator should also have the skills to support students to enhance their active learning. This theory claims that students must be taught to actively construct knowledge for themselves - the student is, therefore, an 'active agent in the process of knowledge acquisition' (Bada 2015:66), updating their accommodation (i.e. their personal mental capacity models), while constructing new understandings with assimilation (using their existing knowledge) (cf. Bada 2015:66-67).

Within constructivism, learning is an active process operated by the student who is the centre of the learning activity. The educator then becomes a facilitator in the student's learning process and problem-solving environment (cf. Bada 2015:69). To accomplish this, educators must become change agents who ground their actions in sound moral decisions and embrace the tools that technology provides education with. They must be self-directed, lifelong learners who initiate innovative and life-changing projects that bring positive change to South African communities.

\section{Literature overview}

During the 1950s, change agency as a group or team bringing about change was mostly the point of discussion (cf. Lewin 1951; Trist \& Bamforth 1951), although Lewin (1951) already referred to individual action researchers. Only in 1958 was the term officially defined by Lippitt et al. (1958) when they referred to:

the planned change that originates in a decision to make a deliberate effort to improve the system and to obtain the help of an outside agent in making this improvement. We call this outside agent a change agent. (p. 10)

In 1959, Lippitt described a change agent as a consultant, either in an internal or an external role. Bennis followed in 1964, defining change agents as 'professionals, men [sic.] who, for the most part, have been trained and hold doctorates in the behavioral sciences', consisting of researchers, trainers, consultants, counsellors, teachers and even line managers (Bennis 1964:306; cf. Ottaway 1983:362). While Lippitt et al. put emphasis on the external change agent, Bennis (1969:8) stated that the change agent can be either from outside or from inside. In 1969, Bennis and Schein narrated the anecdote of the Undercover Change Agent 'who attempted to conduct an unauthorized $\mathrm{T}$ Group which resulted in him being fired and only technical training being allowed in the future' (Bennis \& Schein 1969:335-357), focusing on the role of the change agent. Still, in 1969, Kraak referred to managers as change agents, with emphasis on their training. Beckhard linked with Bennis (1964), stating that change agents 'refer to those people, either inside or outside the organization, who are providing technical, specialist or consulting assistance in the management of a change effort' (Beckhard 1969:101). The last 1969 entry belongs to Jones (1969:192), who argued in line with Lippitt et al. stating that a change agent is a helper, a doer or a mover 'employed by the client system to assist achieving improved performance'. This change agent is professional and equipped with the relevant skills and knowledge to make an improvement within an organisation.

In 1970, Argyris argued that the change agent is an interventionist - a consultant or researcher (Argyris 1970:20). The following year, Gross, Giaquinta and Bernstein (1971:29) focused on the role of the educator as change agent, arguing that it is 'assumed that a strategy of initiation involving a change agent and subordinate participation typically leads to the successful implementation of innovations'. Reddin (1971:ix) again focused on the external change agent, but seemingly put more emphasis on the task: 'For the past several years I have worked with several companies as a change agent. Change agents have been called consultants in behavioral clothing'. Rogers and Shoemaker (1971) focused on the change agent within the area of diffusion and innovation (cf. Ottaway 1983:364), arguing that a 'change agent is a professional who influences innovation decisions in a direction deemed desirable by a change agency' (Rogers \& Shoemaker 1971:35). The term 'professional' referred to here can be inside or outside the organisation (Rogers \& Shoemaker 1971:227). Weir and Mills (1973:61-69) regarded the change agent as a supervisor, who needs to be informed and brought into the process. The definition of Hall and Williams (1973:2) broadened the scope of assistance by the 
change agent also to the individual: 'Let us define change agents [as] those individuals in our society who have the role of bringing about constructive change in either other individuals or social organizations and institutions'. In 1973, Pincus and Minahan discussed, in line with Lippitt et al. (1958), the social worker as change agent. Lundberg (1974) stated in the same tradition:

While everyone in the very loosest sense is an agent of change, I refer here to those people who usually have an allegiance to a behavioral science discipline, and who assist and implement the planned change resulting from social interventions in a variety of situations. (p. 69)

Also in 1974, Dale shifted the focus away from the task completed by a change agent to the processes being involved: 'By "change agent" I mean those who seek to help others (singly or in organizations) with their processes of problemsolving and change, without themselves becoming involved in the content' (Dale 1974:102; his emphasis). In the same year, Tichy described the change agent as a facilitator. A year later, Tichy (1975:772) defined a change agent as a social change agent, relating that ' $[\mathrm{t}] \mathrm{he}$ agents in our study are individuals whose primary role is to deliberately intervene into social systems in order to facilitate or bring about social change'. Kahn (1976:496) put emphasis on the behaviour of the change agent, stating, 'To change an organization means changing the pattern of recurring behavior'. Steele (1975) pictured the change agent as a consultant and consulting, emphasising the process. Huse (1975:2-3) was a follower of Bennis, also referring to the role of a change agent. In line with Lippitt (1959), Blake and Mouton (1976:7) talked about a change agent as a consultant. In line with Rogers and Shoemaker, Zaltman and Duncan (1977:186) stated that a change agent is 'any individual or group operating to change the status quo in a system such that the individual or individuals involved must learn how to perform their role(s)', adding that change agents are 'actors in the change process' (Zaltman \& Duncan 1977:183). De Board (1978) wrote in the same vein, calling the change agent an analyst. French and Bell (1978:16) preferred the term catalyst.

The notion of a change master or transformational leader(ship) was the point of discussion in the literature of the 1980s and the 1990s. During these decades, it was expected from the prospective change agent to focus on technological innovation, coping with all the uncertainties linked to the unfamiliar technology, and being a risk taker. Kuhr (1980:27) discussed change agency as management consulting, describing it as follows: 'Not only to give the right advice, but to give it in the right way at the right time - this is a basic skill of a consultant'. Kirton (1980) called the change agent an adaptor or innovator. Fullan (1982) narrated the roles and strategies of various types of change agents. Blake and Mouton (1983), as well as Kanter (1984), defined a change agent as a catalyst (like French \& Bell 1978) or corporate entrepreneur. Lawler (1986) and Schein (1988) also emphasised the individual, respectively calling the change agent an empowerer and a process consultant. Proponents like Devanna and Tichy (1986) referred to change agents as charismatic heroes who transform the society and have the intention to get rid of rigid and inflexible structures, thereby becoming change champions. During this decade, the scholars who defined change agents as groups are Meadows (1980), who referred to an organic group, and Juran (1985) who spoke of a quality circle.

The 1990s built on the previous decade, with Fullan and Stiegelbauer (1991) taking the premise of Fullan (1982) further concerning the roles and strategies of various types of change agents. Most of the scholars in the 1990s focused on the individual change agent, called developer (Pedler, Burgoyne \& Bydell 1990), transformational leader (Bass 1990), patriarchs, who originate ideas, and evangelists who implement them (Beatty \& Gordon 1991), pathfinder (Beatty \& Lee 1992), changemaker (Storey 1992), visionary (Bennis 1993), charismatic leader (Conger \& Kanungo 1993), change leader (Kotter 1996), expert (Cummings \& Worley 1997), sponsor (Connor 1998) and counsellor (Feltham 1999). In line with Devanna and Tichy (1986), Ulrich (1997) and Conger and Kanungo (1993) referred to change agents as charismatic heroes, becoming change champions. The scholars who defined change agents as groups are Beer, Eisenstat and Spector (1990), discussing a task group, West (1990:309-333) using Team Climate Inventory (TCI) to refer to change agency, Kanter (1999) referring to a transitional team (whereas in 1984 he used the term corporate entrepreneur) and Senge (1999) who used the term pilot group. Instead of defining a change agent or group clearly, certain scholars rather conflated change agency, using a single model and ascribing certain competencies to the successful change agent (cf. Hartley, Bennington \& Binns 1997:68), acting as a bridge to the 21st century.

In the first part of the 21st century, the classification of literature has become diverse, as most of the scholars are not anymore opting for a group or an individual; the notion of change agency is rather discussed. Examples are Barlas (2001:8) who did research on change agency within adult relationships, describing change agency more on a personal level, from the view of the student within the environment of an educator. Schwier, Campbell and Kenny (2004) and Campbell, Schwier and Kenny (2009:645-663) investigated the role of an instructional designer in change agency. Diamond (2005) looked at institutional change agency, with reference to educational support centres. Buchanan et al. (2007) discussed distributed change agency, consisting of small teams and senior groups, while Chreim et al. (2010) elaborated on distributed leadership as collective leadership. Charles and Dawson (2011) were referring in the same vein to dispersed change agency in change teams. Ożga and Stelmaszczyk (2016) took another angle when they discuss the internal change agent who develops a relationship between knowledge sharing and performance in a virtual team.

More in line with the early 1990s, scholars like Caldwell (2001; cf. Caldwell 2003:131) still referred to Tichy (1974:164-182), 
focusing on an individual external facilitator or change manager who has to plan 'processes of evolutionary change'. Rogers (2009) talked about the change agent as an individual who influences others, while McCormack et al. (2013) elaborated on change agents as facilitators, knowledge brokers and opinion leaders, although their definition of change agency is more focused on the organisation. Grimshaw et al. (2012:50-57), Greenhalgh et al. (2004:581-629), as well as McCormack et al. (2013:3 of 12) did research on 'What change agency characteristics work, for whom do they work, in what circumstances and why?' and defined change agency as an 'organization or other unit that promotes and supports adoption and implementation of innovations'. Couros (2015) inspected the mindset of the change agent as innovator.

This overview supplies information about the movement within the notion of change agent and change agency, and brings one to the conclusion that a change agent can be a group or an individual who focuses on assisting or guiding an organisation in bringing about change or who does it herself or himself. Next, this will be elaborated upon under the classification of change agents and change agency.

\section{Models of change agency}

Change agency is characterised in so many ways and categorised so diversely that almost any model or definition pointing in the direction of assistance or change will do. The more scholars write about change agents and change agency, the more models are created. Already in 1983, Ottaway put it this way: 'At the present time the term change agent is nearly unrestricted' (Ottaway 1983:372). This is partly supported by Thompson, Estabrooks and Degner (2006:691-701), who concluded that considerable confusion exists when referencing to change agency terms such as opinion leaders, facilitators and champions. McCormack et al. (2013:2 of 12) referred to change agency with 'the complexity of the term itself, the lack of precision in defining the term, and the multiplicity of associated terms'.

Leavitt (1965:1144-1170) identified four interacting variables of organisational change: task, people, technology and structure. He calls the last three 'potential strategies for organizational change', attracting specialists to build their own change strategies to improve the task performance of the organisation:

- The people specialist focuses on personnel placement, development programmes, job counselling and human relations inside the organisation.

- The technology specialist is the computer expert, the system designer and/or the production engineer who bring about change through technology.

- The structure specialist is focused on the planning inside the organisation, on workflow and the configuration of the staff.
Chin and Benne (1969:58-59) proposed a threefold classification of change agents, actually depicting three stages of change agency:

- Normative-Reeducative agents who work within the paradigm of therapists, trainers and situation changers. This is the unfreezing stage of change agency.

- Power-Coercive agents who bring about change through power and coercion. This represents the change or move stage.

- Rational-Empirical agents who act within the confines of the enlightenment or classical liberalism. This represents the refreezing stage.

The first stage is when someone wants change (unfreeze), then the change happens with new behaviours being taught to those involved (change or move), and after some time this then becomes the status quo (refreeze).

Jones (1969:8) distinguished two types of change agents (called 'actors'):

- The primary actors are change agents who are regarded as the 'client system': Their role is to 'clarify the goals of change for the client system', to develop useful strategies for the solution of the system's problems, and to create an appropriate working relation between everybody involved.

- The secondary actors are the catalysts and pacemakers (cf. Jones 1969:46). The catalyst decides on the pace of the change within the system, while the pacemaker is 'involved in the regulation and control of the planned organizational change' (Jones 1969:60). The pacemaker is responsible for the equilibrium in the client system.

Havelock and Havelock (1973:60) indicated four primary ways for people to act as change agents, and eventually become 'masters of the change process' (Havelock \& Havelock 1973:70). These change agents work in tandem, succeeding each other in specific stages of change agency:

- The catalyst: Although people are normally against change, this change agent 'prods' people to change, especially by upsetting the status quo and by getting things started (cf. Havelock \& Havelock 1973:61).

- The solution giver: This person usually takes the process further with definite ideas and solutions about the course of the change (cf. Havelock \& Havelock 1973:62).

- The process helper: The process helper is specifically tasked to assist the client on how to change (cf. Havelock \& Havelock 1973:63).

- The resource linker: This agent brings people together and helps them to 'find and make the best use of resources inside and outside their own system' (Havelock \& Havelock 1973:63).

Tichy (1974:168; also cf. Tichy 1975) described four types of change agents:

- The Outside-Pressure type: These agents are militants who seek change through mass demonstrations and violence. 
- The Organisation-Development type: These agents observe an organisation critically from the inside in an attempt to improve its capabilities.

- The People-Change-Technology type: These agents use techniques such as behaviour modification to improve the functioning of individuals in an organisation.

- The Analysis-for-the-Top type: They consult with organisations to improve their efficiency and output.

Ganesh (1978:1-28) worked on the model of Leavitt (1965) and reduced it to two categories:

- 'people approach' agents

- 'task and structure approach' agents.

In line with scholars of his time, Duncan (1978) used the term facilitator, referring to the change agent as an individual or a group who initiates or facilitates change. He classified them as:

- an external pressure group

- an internal pressure group

- an organisational development consultant

- an internal change agent/consultant. (p. 362ff.)

Ottaway (1983) identified 10 groups of change agent roles divided into three categories - change generators, implementers and adopters - where one role does not exclude the other. In his identification, he focuses on the role of each agent. His taxonomy is as follows (Ottaway 1983):

- Change generators:

- key change agents (the initiators of an issue)

- demonstrators (demonstrate their support of the proposed change)

- patrons (generate support for the change)

- defenders (defend the change process).

- Change implementers:

- external implementers (people from outside the organisation who are invited to assist with change)

- external/internal implementers (external agents must develop and train internal implementers)

- internal implementers (they implement the change in the organisation).

- Change adopters (they practise and normalise the change):

- early adopters (they are the prototypes of the adoption of change in the change process)

- maintainers (they adopt the change while maintaining their commitment to the organisation)

- users (they make a habit of using the change that occurred). (pp. 375-376)

Adopting the definition of Kahn (1976), Ottaway (1983:377) focused on the behavioural change of individuals, groups, organisations, communities and society. He argued that the change agent acts in a process to change the code of behaviour that was adopted by a group or institution as just, proper or ideal. In line with Lewin (1952:8), Ottaway outlined the task of a change agent as unfreezing, moving and refreezing, linking these three steps to his category of three change agents (Ottaway 1983):

- Change generators are the unfreezers.

- Change implementers are the movers.

- Change adopters are the refreezers. (p. 377)

With reference to the 10 groups indicated above, Ottaway (1983) stated:

- Every person is a change agent - consciously or unconsciously. In different situations, one may even assume different roles, like being a user when referring to the school one's children attend, but a maintainer in the workplace.

- When change starts in an institution, the change agents are in the minority but focused, while at the end of change, they are in the majority and not so focused anymore.

- Every process needs all of the 10 groups identified by Ottaway (some for shorter time spans than others), otherwise change will not fully take place. While the maintainers and the users are the least aware of their roles, they are actually the ones that ensure that the initiated change happens because they adopt it.

- The 10 groups are listed in chronological order. The implication is that refreezers cannot start before the movers have finished their part.

- The role of all change agents is equally important.

- In a change process, a change agent can only fulfil one function, although the agent can fulfil different functions in different processes.

- All the agents in a change process are sharing the same common values. (pp. 379-381)

Buchanan and Storey (1997:127-145) identified eight roles, arguing that the ability to perform several roles, and to switch between them, requires critical competencies. Such taxonomies imply that change agency roles are limited in numbers and codifiable. The roles are those of the initiator, sponsor, driver, subverter, passenger, spectator, victim and 'paramedic' (helping others through the traumas of change) (Buchanan \& Bradley 2008:7). According to them, an individual can play more than one role at the same time (in opposition to Ottaway).

Caldwell, discussing the works of scholars up to 2002, classified all the sources relating to change agency into leadership, management, consultancy and team models (Caldwell 2003):

- Leadership models: In these models, leaders and senior executives act as change agents. They are the ones who 'envision, initiate or sponsor strategic change of a farreaching or transformational nature'.

- Management models: Here the change agents are middle-level managers and functional specialists. They 'adapt, carry forward or build support for strategic change within business units or key functions'. 
- Consultancy models: Internal or external consultants operate as change agents within the organisation. They are required to provide their expertise and advice with regard to project management, changing programme co-ordination or process skills.

- Team models: These teams are represented by workers at all levels within an organisation, including internal and external consultants. (pp. 132, 140)

Schwier, Campbell and Kenny (2007:1-18) have also decided on four categories, relatively in line with Caldwell, calling them interpersonal, professional, institutional and societal models, referring to them as 'a complex and reflexive "agentic model of instructional design" with both intentional and operational dimensions'.

From the above-mentioned models, it is clear that change agency is an interrelated action or function, dependent on the collaboration, assistance and guidance of others inside (or outside) the organisation.

\section{Change agency within higher education}

Notwithstanding the diversity of definitions and models on change agency, there is one common denominator: change - and applied to higher education in South Africa, implicating that things cannot stay as they are; change is needed, and more radical change should be made inevitable. Statements like these evoke a myriad of questions. The most crucial questions in our situation could well be: should change agency be implemented by government and forced downward through the institutions of higher education till it reaches the students (top-down approach)? Alternatively, should the educator or educators on a personal level start with an enthusiastic approach, hoping to motivate everybody around them to such an extent that it will influence their institution, and even the Ministry of Higher Education (bottom-up approach)? While the first question or proposal is the dream answer, the realist answer (cf. McCormack et al. 2013) lies in (a part of) the second question or premise.

\section{Characteristics of change agents}

Personal change does not equal organisational change, as the latter is 'rarely implemented by one person' (Buchanan et al. 2007:1066). Although Buchanan and Bradley (2008) argue that a person can fulfil more than one role in change agency, Ottaway (1983) argues that only one role can be ascribed to one specific person in a specific process. Therefore, a single person is unable to fulfil all the roles of a change agent simultaneously - being a single/'alone' change agent in an organisation. That is why it is recommendable to start with a group of change agents and to get agents from outside to address the institution on change agency when starting the process. Under this heading the specific interventions that a change agent (an individual or a group) should take to bring about change in an institution of higher education (cf. McCormack et al. 2013:3 of 12) are discussed.

As the notion of change agency has not yet found application in many institutions of higher education in South Africa, it looks obvious that an enthusiastic individual or group will have to start the process - bottomup. That individual or group should display specific characteristics, as Gladwell (2002:33) clearly states: 'The success of any kind of social epidemic is heavily dependent on the involvement of people with a particular and rare set of social gifts'. This 'rare set of social gifts' can also be described as characteristics. The initial characteristic a change agent (as individual or as group) should have, is a clear vision about the proposed change, linked to the ability to communicate it clearly to the relevant people in the institution (cf. Couros 2013). With time this communication should create a culture of change within the institution (called 'organizational culture' by McCormack et al. 2013:7 of 12), without which no change can take place successfully. It is important that this clear vision should accommodate the strengths and weaknesses of everybody involved, in order for them to work together to a common purpose (Couros 2013). The change agent should build a strong relationship with everyone (faculty) at the institution, showing them that they can trust the change agent. Trust embodies approachability and reliability, and the ability to show the institution that the agent takes full responsibility for the process (cf. Redfern \& Christian 2003:225-238), coupled with credibility (cf. Covey 2004-2006:5) and accountability (McCormack et al. 2013:6 of 12).

The trust and respect of the institution in the change agent will grow when it becomes clear that the change agent is knowledgeable and willing to take (or be part of - Manley \& McCormack 2003:22-29) the lead in the change process (cf. Couros 2013; Stanley 2006:108-111). The change agent should be a role model during the whole process (McCormack et al. 2013:6 of 12). Transparency is of utmost importance in showing knowledgeableness by constantly delivering papers at the institution, publishing academic articles and engaging in constant reflective practice (McCormack et al. 2013:6 of 12). By doing this, the change agent will further develop the organisational culture in order to be ready to accept the change (cf. Couros 2013), and to start being supportive of everyone involved (Pepler et al. 2006:23-33). In addition, and very importantly, the change agent must also be culturally compatible in terms of the target group (McCormack et al. 2013:8 of 12).

Change agency is not something that must happen out there, or happens with the educator - it is something that must happen inside the educator. Herda (1999:25) argues that change agency is a process in which 'we play a dynamic and crucial role in shaping our own structures and processes whether we are aware of doing this or not' (cf. Campbell et al. 2009:2). This will result in changing actions, which will have a 'significance in our own lives and in the lives of our participants' (Herda 1999:91). 
The two (initial) changes, according to Herda (1999:91), that should take place are, firstly, to stop acting from the basis of behaviourism (i.e. stimulus and response) and start with actions grounded in moral decisions and, secondly, to change one's idea of professional identity. Both of these fit in perfectly with the characteristics needed by theological educators to become change agents.

\section{Theological educators as change agents}

Since the earliest times of human development, religion influenced and shaped the minds and actions of people. Religion, in this case Theology, cultivates citizenship through the formation of individual character trends and habits. Theology should, therefore, function in the epicentre of society (Tracy 2002) to promote change, renewal and transformation. To ensure that Theology will retain this position in society (which was sadly neglected in the past decades in South Africa), theological educators must develop the following characteristics that equip change agents for their tasks:

- Trustworthy role models: Despite secularisation, syncretism and the push towards acceptance of the equality of all religions, Christian educators must practise their faith actively and publicly with integrity and conviction. This will expose the fallacy of privatisation of faith where Christians show no distinctive characteristics and actions that separate them from non-Christians. Famous Christian leaders (like the apostles and church fathers and mothers) and change agents (like the Reformers) through the ages clung to and practised their faith despite contravening world views and even opposing fallacies in the church (cf. Hill 2005; Schmidt 2004; Sunshine 2009). Without this foundational characteristic, there can be no credibility of the theologian as change agent.

- Technologically literate and connected: Theologians must embrace and adapt to the technology-based network society of the 21st century and implement the tools provided by technology to enhance their educational strategies, modes of delivering course activities and assessment methods. In the past, theologians implemented the latest developments in communication technology (which were the development of language, writing and printed material) to advance the spreading of the gospel and their own competencies as educators (Oliver 2014).

- Self-directed lifelong learners: To function optimally as knowledge and skills brokers, theological educators must take responsibility for their own advanced learning (in addition to and often outside of their fields of specialisation). They also need skills and competencies to act as change agents both in the structure of the institution and to their students. This requires an intentional cognitive leap from the structured and paced mass education systems to thinking and acting differently in all aspects of education. Development of a new view of education and advanced learning by educators would promote the attitude and behavioural change of both educators and students who will be able to function as successful change agents (Oliver 2016:3-4 of 7).

- Applying positive and daring innovation: South Africa needs positive, active and responsible citizens who can initiate change by being involved in community upliftment projects. Throughout the ages, theologians spoke out for and acted on behalf of the marginalised, victimised and isolated groups and individuals. The current situation in South Africa offers ample opportunities for theologians to facilitate positive change in faith communities and the lives of students (cf. Oliver et al. 2017).

\section{Conclusion}

For the past 70 years, 'change agents' and 'change agency' were described through various definitions and models in order to make sense of this complex phenomenon. Some scholars regarded change agency as a group activity, while others believed that the individual can also act as a successful change agent. During the past two decades, scholars displayed a more diverse view and preferred discussing the notion of change agency.

The descriptive nature of the article does not allow to choose between the individual or group approaches to change agency, nor for preference of one model over another. The extensive review on change agency allowed the researcher to touch on the characteristics that a change agent should display. It also provided an opportunity to list a few important characteristics that theologians in the higher education sphere should cultivate to become active agents of positive change. Proclaiming our faith and convictions and also speaking and acting in accordance with these convictions are the most important characteristics of the Christian change agent. This establishes trustworthiness and identifies theologians as competent leaders who expand their knowledge and skills and competencies through the use of the latest developments in technology to ensure that Theology stays relevant to address the problems and issues of the South African society. Theological educators must set the example of what it means to be change agents by implementing and managing creative projects aimed at community upliftment and sustainable development.

Educational change does not happen overnight. Patience and persistence should be characteristics of a determined and enthusiastic change agent and can also function as educators for the change agent in the process of lifelong learning.

\section{Acknowledgements Competing interests}

The author declares that she has no financial or personal relationships which may have inappropriately influenced her in writing this article. 


\section{References}

Ally, M., 204, 'Foundations of educational theory for online learning', in T. Anderson \& F. Elloumi (eds.), Theory and practice of online learning, pp. 3-31, Athabasca University, Athabasca.

Alzahrani, I. \& Woollard, J., 2013, 'The role of the constructivist learning theory and collaborative learning environment on wiki classroom, and the relationship between them', paper delivered at the 3rd International Conference for e-learning \& Distance Education, Riyadh, 4-7th February, pp. 1-9.

Argyris, C., 1970, Intervention theory and method, Addison-Wesley, Reading, MA

Attard, A., 2010, Student centered learning: An insight into theory and practice, Partos Timisoara, Bucharest.

Bada, S.O., 2015, 'Constructivism learning theory: A paradigm for teaching and learning', Journal of Research \& Method in Education 5(6), 66-70.

Barlas, C., 2001, 'Learning-within-relationship as context and process in adult education: Impact on transformative learning and social change agency', Pape presented at the 42nd Annual Meeting of the Adult Education Research Conference, Lansing, Ml, 1-3 June, viewed 30 May 2018, from http://www.edst. educ.ubc.ca/aerc/2001/2001barlas.htm

Bass, B.M., 1990, 'From transactional to transformational leadership: Learning to share the vision', Organizational Dynamics 18(3), 19-31. https://doi.org/10.1016/ 0090-2616(90)90061-S

Beatty, C.A. \& Gordon, J.R.M., 1991, 'Preaching the gospel: The evangelists of new technology', California Management Review 33(1), 73-94. https://doi.org/ 10.2307/41166662

Beatty, C.A. \& Lee, G.L., 1992, 'Leadership among middle managers: An explanation in the context of technological change', Human Relations 45(9), 957-989. https:// doi.org/10.1177/001872679204500905

Beckhard, R., 1969, Organizational development: Strategies and methods, AddisonWesley, Reading, MA.

Beer, M., Eisenstat, R.A. \& Spector, B., 1990, 'Why change programmes don't produce change', Harvard Business Review 68(6), 158-166.

Benne, K.D., 1976, 'The process of re-education: An assessment of Kurt Lewin's views', Group and Organization Studies 1(1), 26-42. https://doi.org/10.1177/ 105960117600100104

Bennis, W.G., 1964, 'The change agents', in R.T. Golembiewski \& A. Blumberg (eds.) Sensitivity training and the laboratory approach, pp. 306-321, F. E. Peacock Publishers, Itasca, IL.

Bennis, W.G., 1969, Organizational development: Its nature, origins, and prospects, Addison-Wesley, Reading, MA

Bennis, W.G., 1993. An invented life: Reflections on leadership and change, AddisonWesley, Reading, MA.

Bennis, W.G. \& Schein, E.H., 1969, 'Principles and strategies in the use of laboratory training for improving social systems', in W.G. Bennis, K.D. Benne \& R. Chin (eds.), The planning of change, 2 nd edn., pp. 335-357, Holt, Rinehart and Winston, The plann

Blake, R.R. \& Mouton, J.S., 1976, Consultation, Addison-Wesley, Reading MA.

Blake, R.R. \& Mouton, J.S., 1983, Consultation: A handbook for individual and organizational development, Addison-Wesley, Reading, MA.

Buchanan, D.A., Addicott, R., Fitzgerald, L., Ferlie, E. \& Baeza, J.I., 2007, 'Nobody in charge: Distributed change agency in healthcare', Human Relations 60(7), 1065-1090. https://doi.org/10.1177/0018726707081158

Buchanan, D.A. \& Bradley, R.J., 2008, Power, politics, and organizational change: Winning the turf game, 2nd edn., Sage, London.

Buchanan, D.A. \& Storey, J., 1997, 'Role taking and role switching in organizationa change', in I. McLoughlin \& M. Harris (eds.), Innovation, organizational change and technology, pp. 127-145, International Thomson, London.

Caldwell, R., 2001, 'Champions, adapters, consultants and synergists: The new change agents in HRM', Human Resource Management Journal 11(3), 39-52. https://doi. org/10.1111/j.1748-8583.2001.tb00044.x

Caldwell, R., 2003, 'Models of change agency: A fourfold classification', British Journal of Management 14(2), 131-142. https://doi.org/10.1111/1467-8551.00270

Campbell, K., Schwier, R.A. \& Kenny, R.F., 2009, 'The critical, relational practice of instructional design in higher education: An emerging model of change agency' Educational Technology Research and Development 57(5), 645-663. https://doi. org/10.1007/s11423-007-9061-6

Charles, K. \& Dawson, P., 2011, 'Dispersed change agency and the improvisation of strategies during processes of change', Journal of Change Management 11(3) 329-351. https://doi.org/10.1080/14697017.2011.576653

Chin, R. \& Benne, K.D., 1969, 'General strategies for effecting change in human systems', in W.G. Bennis, K.D. Benne \& R. Chin (eds.), The planning of change, 2 nd edn., pp. 32-59, Holt, Rinehart and Winston, New York.

Chreim, S., Williams, B.E., Janz, L. \& Dastmalchian, A., 2010, 'Change agency in a primary health care context: The case of distributed leadership', Health Care Management Review 35(2), 187-199. https://doi.org/10.1097/HMR.0b013 e3181c8b1f8

Conger, J.A. \& Kanungo, R.N., 1993, Charismatic leadership in organizations, Sage, New York.

Connor, D.R., 1998, Managing at the speed of change, John Wiley \& Sons, Chichester.
Couros, G., 2013, 'The principal of change: Stories of learning and leading - 5 Characteristics of a change agent', viewed 28 May 2018, from https:// georgecouros.ca/blog/archives/3615

Couros, G., 2015, The innovator's mindset: Empower learning, unleash talent, and lead a culture of creativity, Dave Burgess Consulting, San Diego, CA.

Covey, S.M.R., 2004-2006, 'The 13 behaviors of a high trust leader', 6 p., viewed 31 May 2018, from https://csdaca.org/wp-content/uploads/2016/08/Handout13Behaviors.pdf

Cummings, T.G. \& Worley, C.G., 1997, Organizational development and change, South Western College Publishing, Cincinnati, $\mathrm{OH}$.

Dale, A., 1974, 'Coercive persuasion and the role of the change agent', Interpersona Development 5(2), 102-111.

De Board, R., 1978, The psychoanalysis of organizations, Tavistock, London.

Devanna, M.A. \& Tichy, N.M., 1986, 'The transformational leader', Training and Development Journal 40(7), 27-32.

Diamond, R.M., 2005, 'The institutional change agency: The expanding role of academic support centers', in S. Chadwick-Blossey (ed.), To improve the academy: Resources for faculty, instructional and organizational development, vol. 23, pp. 24-37, A publication of the POD Network, Anker Publishing Company, Bolton, MA.

Duncan, W.J., 1978, Organizational behaviour, Houghton Mifflin, Boston, MA.

Feltham, C. (ed.), 1999, Controversies in psychotherapy and counselling, Sage, New York.

Foster, M., 1972, 'An introduction to the theory and practice of action research in work organizations', Human Relations 25(6), 529-556. https://doi.org/10.1177/ 001872677202500605

French, W.L. \& Bell, C.H., 1978, Organization development, Prentice-Hall, Englewood Cliffs, N.J.

Fullan, M., 1982, The meaning of educational change, Teachers College Press, New York.

Fullan, M. \& Stiegelbauer, S., 1991, The new meaning of educational change, 2nd edn., Teachers College Press, New York.

Ganesh, S.R., 1978, 'Organizational consultants: A comparison of styles', Human Relations 31(1), 1-28. https://doi.org/10.1177/001872677803100101

Gladwell, M., 2002, The tipping point: How little things can make a big difference, Back Bay Books, Open Internet Library.

Greenhalgh, T., Robert, G., Bate, P. \& Kyriakidou, O., 2004, 'How to spread good ideas: A systematic review of the literature on diffusion, dissemination and sustainability of innovations in health service delivery and organisation', Milbank Quarterly 82(4), 581-629. https://doi.org/10.1111/j.0887-378X.2004.00325.x

Grimshaw, J.M., Eccles, M.P., Lavis, J.N., Hill, S.J. \& Squires, J.E., 2012, 'Knowledge translation of research findings', Implementation Science 7, 50-57. https://doi. org/10.1186/1748-5908-7-50

Gross, N., Giaquinta, J.B. \& Berstein, M. 1971, Implementing organizational Innovations, Harper and Row, New York.

Hall, C.S. \& Lindzey, G., 1978, Theories of personality, 3rd edn., Wiley, New York.

Hall, J. \& Williams, M.S. 1973, How to interpret your scores from the change agent questionnaire, Teleometrics International, Conroe, TX.

Hartley, J., Bennington, J. \& Binns, P., 1997, 'Researching the roles of internal change agents in the management of organizational change', British Journal of Management 8(1), 61-73. https://doi.org/10.1111/1467-8551.00040

Havelock, R.G. \& Havelock, M.C., 1973, Training for change agents: Center for research of utilization of scientific knowledge, Institute for Social Research, The University of Michigan, Ann Arbor, MI.

Herda, E.A., 1999, Research conversations and narrative: A critical hermeneutic orientation in participatory inquiry, Praeger, London.

Hill, J., 2005. What has Christianity ever done for us? How it shaped the modern world, Intervarsity Press, Downers Grove, IL.

Huse, E.F., 1975, Organization development and change, West, New York.

Jones, G.N., 1969, Planned organizational change, Routledge and Kegan Paul, London. Juran, J.M., 1985, Quality control handbook, McGraw-Hill, New York.

Kahn, R.L., 1976, 'Organizational development: Some problems and proposals', Journal of Applied Behavioral Science 10(4), 485-502. https://doi.org/10.1177/ 002188637401000403

Kanter, R.M., 1984, The change masters, Allen \& Unwin, London.

Kanter, R.M., 1999, On leading change, Simon \& Schuster, London.

Kirton, M.J., 1980, 'Adaptors and innovators', Human Relations 3, 213-224. https:// doi.org/10.1177/001872678003300401

Kotter, J., 1996, Leading change, Harvard Business School Press, Boston, MA.

Kraak, J.H., 1969, 'Training managers in developing countries as "change agents", paper to the International Seminar on Management Development for the developing countries, Palermo, Italy, June 1969 (mimeographed).

Kuhr, M., 1980, Management consulting, International Labour Office, Geneva.

Lawler, E.E., 1986, High involvement management, Jossey-Bass, San Francisco, CA.

Leavitt, H.J., 1965, 'Applied organizational change of industry: Structural, technological and humanistic approaches', in J.G. March (ed.), Handbook of organizations, vol. 20, pp. 1144-1170, Routledge, London, viewed 28 May 2018, from https://www. amazon.com/Handbook-Organizations-RLE-Routledge-Editions/dp/1138975753 
Lewin, K., 1951, Force field analysis, Harper \& Row, New York.

Lewin, K., 1952, Field theory in social science: Selected theoretical papers by Kurt Lewin. Tavistock, London.

Lippitt, R., 1959, 'Dimension of the consultant's job', Journal of Social Issues 15(2), 5-12. https://doi.org/10.1111/j.1540-4560.1959.tb01442.x

Lippitt, R., Watson, J. \& Westley, B. 1958, The dynamics of planned change, Harcourt, Brace and World, New York.

Lundberg, C.C., 1974, 'Images and meta-styles of change agents: An exploratory note', Interpersonal Development 4(2), 69-76.

MacLellan, E. \& Soden, R., 2004, 'The importance of epistemic cognition in studentcentred learning', Instructional Science 32(3), 253-268. https://doi.org/10.1023/ B:TRUC.0000024213.03972.ce

Manley, K. \& McCormack, B., 2003, 'Practice development: Purpose, methodology, facilitation and evaluation', Nursing in Critical Care 8, 22-29. https://doi. org/10.1046/j.1478-5153.2003.00003.x

McCormack, B., Rycroft-Malone, J., DeCorby, K., Hutchinson, A.M., Bucknall, T., Kent, B. et al., 2013, 'A realist review of interventions and strategies to promote evidenceinformed healthcare: A focus on change agency', Implementation Science 8, 107 $1-12$, viewed 29 May 2018, from http://www.implementationscience.com/ content/8/1/107

Meadows, I.S.G., 1980, 'Organic structure and innovation in small groups', Human Relations 33, 369-382. https://doi.org/10.1177/001872678003300602

Oliver, E., 2014, 'Theological education with the help of technology', HTS Teologiese Studies/Theological Studies 70(1), Art. \#2643, 1-7. https://doi.org/10.4102/hts. v70i1.2643

Oliver, E., 2016, 'A move towards heutagogy to empower theology students', HTS Teologiese Studies/Theological Studies 72(1), a3394. https://doi.org/10.4102/hts. v72i1.3394

Oliver, E., Tsabela, V., Baartman, F., Masooa, A. \& Laister, L., 2017, 'Can Christians really make a difference? A response to the call for change to make the world a better place', HTS Teoligiese Studies/Theological Studies 73(3), 4351. https://doi. better place, , HTS Teoligiese
org/10.4102/hts.v73i3.4351

Ottaway, R.N., 1983, 'The change agent: A taxonomy in relation to the change process', Human Relations 36, 361-392. https://doi.org/10.1177/00187267830 3600403

Ożga, J. \& Stelmaszczyk, M., 2016, 'The role of internal change agent in developing the relationship between knowledge sharing and performance in virtual team' E-mentor 5(67), 62-74. https://doi.org/10.15219/em67.1272

Pedler, M., Burgoyne, J. \& Boydell, M., 1994, A manager's guide to self-development, McGraw-Hill, London.

Pepler, C.J., Edgar, L., Frisch, S., Rennick, J., Swidzinski, M., White, C. et al., 2006 'Strategies to increase research-based practice: Interplay with unit culture', Clinical Nurse Specialist 20, 23-33. https://doi.org/10.1097/00002800-20060 1000-00008

Pincus, A. \& Minahan, A., 1973, Social work practice: Model and method, F.E. Peacock, Itasca, IL.

Reddin, W.J., 1971, Effective management by objectives, McGraw-Hill, New York.

Redfern, S. \& Christian, S., 2003, 'Achieving change in health care practice', Journal of Evaluation in Clinical Practice 9, 225-238. https://doi.org/10.1046/j.13652753.2003.00373.x
Rogers, E.M., 2009, Diffusion of innovations, 3rd edn., Collier Macmillan Publishers, London.

Rogers, E.M. \& Shoemaker, F.F., 1971, Communication of innovations: A cross-cultural approach, 2nd edn., The Free Press, New York.

Schein, E., 1988, Process consultation, Vol. 1: Its role in organizational development, Addison-Westley Publishing, Reading, MA.

Schmidt, A.J., 2004. How Christianity changed the world, Zondervan, Grand Rapids, MI.

Schwier, R.A., Campbell, K. \& Kenny, R.F., 2004, 'Instructional designers' observations about identity, communities of practice and change agency', Australasian Journal about identity, communities of practice and change agency', Australasian Journal
of Educational Technology 20(1), 69-100. https://doi.org/10.14742/ajet.1368

Schwier, R.A., Campbell, K. \& Kenny, R.F., 2007, 'Instructional designers' perceptions of their agency: Tales of change and community', in M. Keppell (ed.), Instructional design: Case studies in communities of practice, pp. 1-18, Idea Group Publishing, design: Case
Hershey, PA.

Senge, P., 1999, 'Learning for a change', Fast Company 24, 178-183.

Stanley, D., 2006, 'Clinical leadership: Recognizing and defining clinical nurse leaders', British Journal of Nursing 15, 108-111. https://doi.org/10.12968/bjon. 2006.15.2.20373

Steele, F., 1975, Consulting for organizational change, University of Massachusetts Press, Amherst, MA.

Storey, J., 1992, Developments in the management of human resources, Blackwell, Oxford.

Sunshine, G.S., 2009. Why you think the way you do: The story of western world views from Rome to home, Zondervan, Grand Rapids, MI.

Swail, W.S., 2002, 'Higher education and the new demographics: Questions for policy', Change 34(4), 15-23.

Tagg, J., 2003, The learning paradigm college, Anker, Bolton, MA.

Thompson, G.N., Estabrooks, C.A. \& Degner, L.F., 2006, 'Clarifying the concepts in knowledge transfer: A literature review', Journal of Advanced Nursing 53, 691-701. https://doi.org/10.1111/j.1365-2648.2006.03775.x

Tichy, N.M., 1974, 'Agents of planned change: Congruence of values, cognitions and actions', Administrative Science Quarterly 19(2), 164-182. https://doi.org/ 10.2307/2393887

Tichy, N.M., 1975, 'How different types of change agents diagnose organizations', Human Relations 23(5), 771-779. https://doi.org/10.1177/001872677502800901

Tracy, D., 2002, 'On theological education: A reflection', in R.L. Petersen \& N.M. Rourke (ed.), Theological literacy for the twenty-first century, pp. 13-22, Eerdmans, Grand Rapids, MI.

Trist, E.L. \& Bamforth, K.W., 1951, 'Some social and psychological consequences of the longwall method of coal-cutting', Human Relations 4(1), 3-38. https://doi.org/ 10.1177/001872675100400101

Ulrich, D., 1997, Human resource champions, Harvard University Press, Cambridge, MA.

Weir, M. \& Mills, S., 1973, 'The supervisor as a change agent', Industrial Relations Journal 4(4), 61-69. https://doi.org/10.1111/j.1468-2338.1973.tb00149.x

West, M.A., 1990, 'The social psychology of innovation in groups', in M.A. West \& J.L. Farr (eds.), Innovation and creativity at work, pp. 309-333, Wiley, Chichester.

Zaltman, G. \& Duncan, R., 1977, Strategies for planned change, Wiley, New York. 